WSRC-TR-97-0153

\title{
Radioactive Release from Aluminum-Based Spent Nuclear Fuel in Basin Storage
}

by

R. L. Sindelar

Westinghouse Savannah River Company

Savannah River Site

Aiken, South Carolina 29808

J. P. Howell

DOE Contract No. DE-AC09-96SR18500

This paper was prepared in connection with work done under the above contract number with the U.S.

Department of Energy. By acceptance of this paper, the publisher and/or recipient acknowledges the U. S.

Government's right to retain a nonexclusive, royalty-free license in and to any copyright covering this paper, along with the right to reproduce and to authorize others to reproduce all or part of the copyrighted paper. 


\title{
Radioactivity Release from Aluminum-Based Spent Nuclear Fuel in Basin Storage (U)
}

\author{
R. L. Sindelar and J. P. Howell \\ Savannah River Technology Center \\ Strategic Materials Technology Department \\ Materials Technology Section \\ Publication Date: May 1997

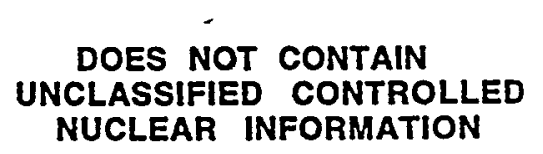 \\ ADC - \&

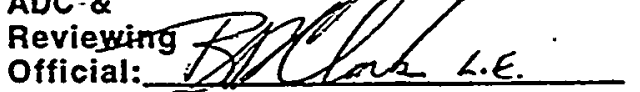 \\ Date:
}

Westinghouse Savannah River Company Savannah River Site Aiken, SC 29808

This document was prepared in connection with work done under Contract No. DE-AC09-96SR18500 with the U. S. Department of Energy 


\section{DISCLAIMER}

This report was prepared as an account of work sponsored by an agency of the United States Government. Neither the United States Government nor any agency thereof, nor any of their employees, makes any warranty, express or implied, or assumes any legal liability or responsibility for the accuracy, completeness, or usefulness of any information, apparatus, product, or process disclosed, or represents that its use would not infringe privately owned rights. Reference herein to any specific commercial product, process, or service by trade name, trademark, manufacturer, or otherwise does not necessarily constitute or imply its endorsement, recommendation, or favoring by the United States Government or any agency thereof. The views and opinions of authors expressed herein do not necessarily state or reflect those of the United States Government or any agency thereof.

This report has been reproduced directly from the best available copy.

Available to DOE and DOE contractors from the Office of Scientific and Technical Information, P.O. Box 62, Oak Ridge, TN 37831; prices available from (615) 576-8401.

Available to the public from the National Technical Information Service, U.S. Department of Commerce; 5285 Port Royal Road, Springfield, VA 22161. 


\section{DISCLAIMER}

Portions of this document may be illegible in electronic image products. Images are produced from the best available original document. 


\section{DOCUMENT: WSRC-TR-97-0153}

TITLE: Radioactivity Release from Aluminum-Based . Spent Nuclear Fuel in Basin Storage (U)

\section{APPROVALS}

Sothindelan.

R.L. Sindelar, Author

Materials Applications \& Corrosion Technology. Group MATERIALS TECHNOLOGY SECTION

$$
\text { 1.P. Howell }
$$

J. P. Howell, Co-author

MATERIALS TECHNOLGGY SECTION

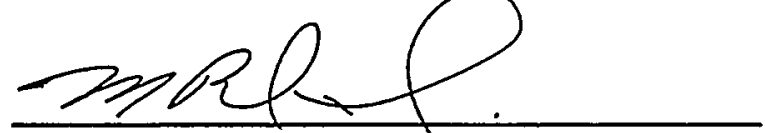

M. R. Louthan, Jr, Technical Reviewer

MATERIALS TECHNOLOGY SECTION

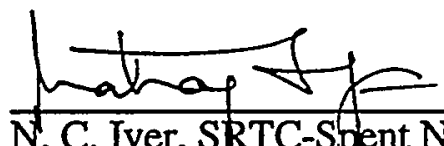

N. C. Iyer, SRTC-Spent Nuclear Fuel Manager

Materials Applications \& Corrosion Technology Group MATERIALS TECHNOLOGY SECTION

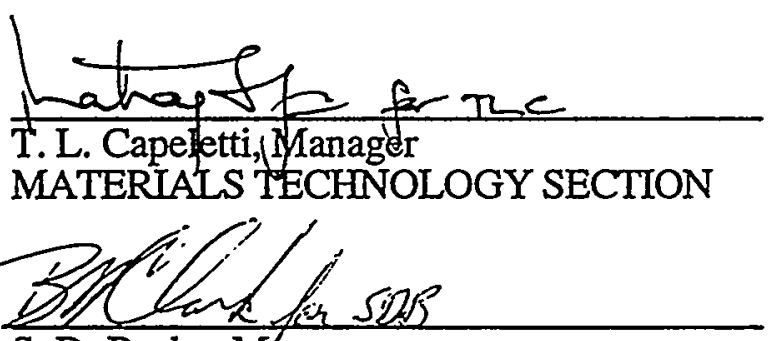

S. D. Burke, Manager

SPENT FUEL STORAGE DIVISION
Date: $5-30-97$

Date: $5-30-47$
Date: $5 / 30 / 97$

Date: $5 / 30 / 97$

Date: $5 / 30 / 47$ 


\section{SUMMARY}

This report provides an evaluation of: 1) the release rate of radionuclides through minor cladding penetrations (breaches) on aluminum-based spent nuclear fuel (Al SNF), and 2) the consequences of direct storage of breached Al SNF relative to the authorization basis for SRS basin operation. The breached reference fuel assembly (BRFA), a fuel assembly at a conservative upper bound reference condition, is defined by a:

- Cs-137 loading of $73.1 \mathrm{Ci} / \mathrm{in}^{3}$ of fuel material ${ }^{1}$; and an

- Exposed fuel core region of $0.5 \mathrm{in}^{2}$.

A model for the release rate from breached fuel in water is developed from consideration of the materials and structure of Al SNF. The model was validated using field data on an assembly with cladding penetrations totaling 0.5 in $^{2}$ of exposed fuel core which bounds the most severely breached fuel assemblies expected to be received in the Foreign Research Reactor Fuel program. A release rate of $9.24 \mathrm{nCi} / \mathrm{hr}$ of $\mathrm{Cs}-137$ was measured for this fuel assembly and is in good agreement with the rate of $15.5 \mathrm{nCi} / \mathrm{hr}$ conservatively predicted from the release rate model. Using the release model, the estimated release rate from the $\mathrm{BRFA}$ into basin water is $0.835 \mu \mathrm{Ci} / \mathrm{hr}(835 \mathrm{nCi} / \mathrm{hr})$ of $\mathrm{Cs}-137$.

The consequences of storing breached fuel relative to the authorization basis is evaluated through the postulated storage of 1500 BRFAs, a number approximately $10 \%$ of the expected receipts from the Foreign Research Reactor program over the next 5 - 10 years. Calculations, based on this storage scenario for both the L-Basin and the Receiving Basin for Off-site Fuels (RBOF), show that the basin water activity levels increase, but remain well within the authorized limits (see Table 1).

Table 1- Estimated Changes in Activity Levels in the SRS Basins for Storage of 1500 Assemblies Each Releasing $0.835 \mu \mathrm{Ci} / \mathrm{hr}$ of $\mathrm{Cs}-137$

\begin{tabular}{|c|c|c|c|c|c|}
\hline Basin & $\begin{array}{c}\text { Present } \\
\text { Steady-State } \\
\text { Basin Activity } \\
\text { Level } \\
\text { w/Deionization } \\
\text { (dpm/ml) }\end{array}$ & $\begin{array}{c}\text { Estimated } \\
\text { Change in } \\
\text { Steady-State } \\
\text { Basin Activity } \\
\text { Level } \\
\text { w/Deionization* } \\
\text { (dpm/ml) }\end{array}$ & $\begin{array}{c}\text { Present } \\
\text { Activity } \\
\text { Increase Rate } \\
\text { w/Inactive } \\
\text { Deionization } \\
\text { (dpm/ml/day) }\end{array}$ & $\begin{array}{c}\text { Estimated } \\
\text { Change in } \\
\text { Activity } \\
\text { Increase Rate } \\
\text { w/Inactive } \\
\text { Deionization* } \\
\text { (dpm/ml/day) }\end{array}$ & $\begin{array}{c}\text { Authorized } \\
\text { Limit for } \\
\text { Water } \\
\text { Activity } \\
\text { (dpm/ml) }\end{array}$ \\
\hline \hline L-Basin & 4 & 61.1 & 0.31 & 5.22 & $\begin{array}{c}2000 \\
\text { (Cs-137) }\end{array}$ \\
\hline RBOF & 259 & 123 & 36 & 35.2 & $\begin{array}{c}220,000 \\
\text { (total) }\end{array}$ \\
\hline
\end{tabular}

* Estimated contribution from the postulated storage of the 1500 BRFAs only

The present activity increase in the basins when the deionization systems are inactive is approximately $0.31 \mathrm{dpm} / \mathrm{ml} /$ day for L-Basin [1] and $36 \mathrm{dpm} / \mathrm{ml} /$ day for RBOF [2]. The current source term for Cs-137 in the L-Basin includes releases from the inventory of "at risk" Mk-16 assemblies together with releases from the basin walls, sludge, and fuel

\footnotetext{
${ }^{1}$ The total cesium content of the BRFA is equal to that of the Reference Fuel Assembly (RFA) used in the authorization basis for the Receiving Basin for Offsite Fuels (RBOF)
} 
surface contamination. The RBOF source term includes releases from the inventory of failed Taiwanese Research Reactor fuel, Heavy Water Components Test Reactor fuel and several other degraded fuels. These rates would increase with the storage of 1500 BRFAs to totals of 5.53 and $71.2 \mathrm{dpm} / \mathrm{ml} /$ day, respectively for L-Basin and $\mathrm{RBOF}$. In the event of inactive deionizer operation when storing 1500 BRFAs, the authorized Cs-137 activity level of $2000 \mathrm{dpm} / \mathrm{ml}$ for L-basin [3] and total activity of $220,000 \mathrm{dpm} / \mathrm{ml}$ for RBOF [4], would not be exceeded for 350 days and 8.5 years, respectively. This provides sufficient time to implement portable deionizer systems that have successfully been used in the past, if such implementation was necessary.

The acceptance criteria for the physical condition of Al SNF for direct storage in SRS basins [5] is derived from present requirements for receipt of foreign research reactor (FRR) fuel [6] and excludes fuels with cladding breaches without canning. This present evaluation predicts the effect of direct storage, without canning, of Al SNF with minor cladding penetrations on basin activity. These results demonstrate that operations would remain well within the authorization basis.

\section{INTRODUCTION}

Approximately 20 metric tons or approximately 15,000 aluminum-based spent nuclear fuel (Al SNF) assemblies will be shipped from foreign research reactors (FRR) to the Savannah River Site (SRS) over the next 10-15 years. These assemblies will be stored at SRS in the L-Basin and the RBOF. A number of these fuel assemblies have corrosion or mechanical damage that has resulted in minor penetrations (breaches) of the aluminum cladding and exposure of the fuel core to the basin water. Corrosion of this exposed core will cause release of radionuclides to the basin water. This report provides an evaluation of the release rates of radionuclides from breached $\mathrm{Al}$ SINF assemblies and evaluates the effect of direct storage of breached fuel at a conservative upper bound reference condition on the basin water activity level and waste generation.

\section{DISCUSSION}

\section{Aluminum-Clad Spent Nuclear Fuel}

Aluminum-based spent nuclear fuel ( $\mathrm{Al} \mathrm{SNF}$ ) is made by powder metallurgy or by casting and rolling. The fuel core for most of these fuels is an aluminum matrix in which particles (dispersoids) of either $\mathrm{UAl}_{\mathrm{x}}, \mathrm{U}_{3} \mathrm{Si}_{2}$, or $\mathrm{U}_{3} \mathrm{O}_{8}$ oxicle particles are embedded. The core is protected by a cladding of aluminum alloy which is metallurgically bonded to the core.

The general structure of the fuel core material, dispersoids in aluminum (Figure 1), is retained following irradiation [7]. Small, uniformly-distributed pockets of fission product gases form within the fuel during irradiation for the $\mathrm{UAl}_{\mathrm{x}}$ and $\mathrm{U}_{3} \mathrm{O}_{8}$ dispersoid fuels; the largest pockets of gas are formed in the high-burnup $\mathrm{U}_{3} \mathrm{Si}_{2}$ dispersoid fuel (Figure 2). The gas pockets are not interconnected. Otherwise, no significant redistribution of the fission products occurs. That is, the fission products are uniformly distributed throughout the fuel core, the fuel/cladding bond is retained, and if the cladding becomes penetrated, only the immediate fuel core area at the point of breach is exposed.

The mechanism for the potential release of radioactive species is quite different for the $\mathrm{Al}$ SNF fuel than for commercial reactor spent fuels. In the case of commercial reactor spent fuel rods, a pin-hole breach in the zircalloy cladding essentially provides a direct path for 
release of fission products from the fuel core region to the surroundings. This is not the case in Al SNF because the fission products are contained locally in the fuel core region.

Breaches in the claddings of Al SNF typically occur through pitting corrosion or mechanical damage. Pitting corrosion is prevalent only under aggressive water chemistry conditions [8-10]. Appendix 1 provides an additional discussion on the corrosion of $\mathrm{Al}$ SNF in basin storage.

Although there are multiple types of aluminum-based fuel, all have the common structure of dispersoids in aluminum and are expected to have similar corrosion behavior and release behavior in high purity water at basin temperatures. The corrosion rate of the exposed fuel decreases slowly with time as a passive film grows on the fuel material. A cladding breach results in a very slow release rate of radioactivity under the low conductivity, high purity storage conditions of the SRS basins.

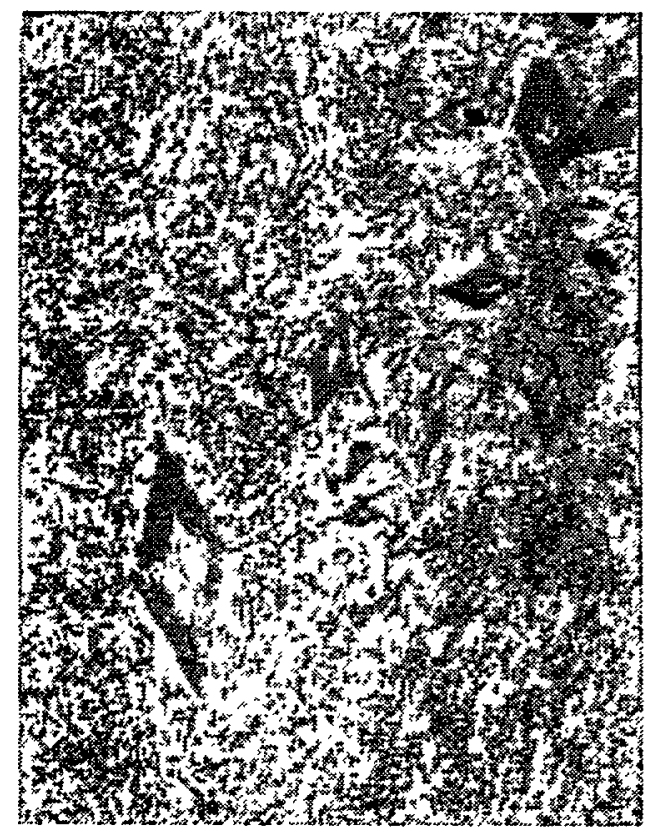

(a) Aluminum-18 wt\% Uranium Longitudinal Direction (500X)

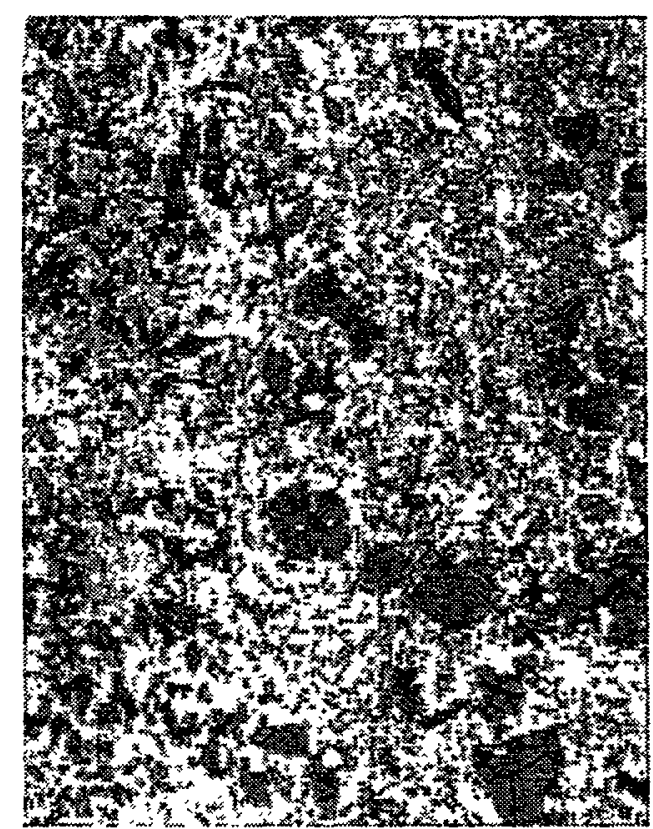

(b) Aluminum-33 wt\% Uranium Longitudinal Direction (500X)

Figure 1- Microstructure of U-Al Alloy Fuel Core Material 


\section{Model for Radioactivity Release Rate from Al SNF}

A model for the radioactivity release rate of fuel with cladding breaches is needed for estimating the release rates from Al SNF representative of the expected receipts. In general, the release rate of radioactivity from Al SNF for a given level of cladding breach is dependent on several factors:

- $\quad$ environment (temperature and quality of the water);

- $\quad$ radioisotope content of fuel (enrichment, burn-up, and decay time);

- fuel core material (post-irradiation composition and microstructure); and

- clad material

At the low temperatures typical of basin storage, corrosion is the primary mechanism whereby species from the fuel core are released into the water. The radionuclides are conservatively assumed to be not bound in the corrosion product, but rather are fully soluble and free to disperse into the water. No significant galvanic interaction between an aluminum-uranium fuel material and aluminum cladding has been measured [10]. Therefore, a simple model to estimate the release from fuel core is developed by considering general corrosion of the fuel core region directly exposed to the environment. The release model is given by:

$\mathrm{R}=\mathrm{A} \times \mathrm{B} \times \mathrm{C}$

where $\mathrm{R}[\mathrm{Ci} / \mathrm{hr}]$ is the total radioactivity release rate;

$\mathrm{A}\left[\mathrm{Ci} / \mathrm{in}^{3}\right]$ is the total radioactivity in the fuel core material at the decay time of interest;

$\mathrm{B}\left[\mathrm{in}^{2}\right]$ is the area of fuel exposed to the environment (area of breach); and

$\mathrm{C}$ [in/hr] is the general corrosion rate of the fuel core material in the environment of exposure (i.e. the corrosion rate is a function of temperature and water quality).

This model can be applied to water storage at temperatures where general corrosion of the exposed fuel is the primary release mechanism $\left(<200^{\circ} \mathrm{C}\right)$. Above this temperature, i) hydrogen blistering attack and exfoliation of the fuel material could occur greatly increasing the rate of attack of the fuel material; and ii) diffusion of radioactive species in the fuel material could occur to allow communication of the bulk fuel core with the exposed surface in direct contact with the water.

Results from laboratory corrosion tests at the Savannah River Technology Center show that both $10 \% \mathrm{U}-\mathrm{Al}$ and 8001 aluminum cladding with fresh surface finishes (600 grit) have a corrosion rate of 0.17 mils per year $\left(2 \times 10^{-8} \mathrm{in} / \mathrm{hr}\right)$ in basin water at room temperature. The fresh surface corrosion rate is expected to be similar for all aluminum-based fuel core materials and can be used as an upper bound estimate of the corrosion rate in basin water. The corrosion rate should decrease slowly with time as a passive film grows on the fuel material in a manner similar to the corrosion of aluminum in water at temperatures less than $100^{\circ} \mathrm{C}$ [11]. For the purpose of this study, a corrosion rate of 0.2 mpy is used to bound the corrosion rate of exposed Al SNF fuel core material in basin water.

\section{Measurements of Release of Radioactivity from Al SNF}

Radioactivity releases from spent fuel can be measured directly by performing a "sip" test. The test is performed by measuring the activity of Cs-137 in a specified volume of water before and after the fuel "rests" in the water for a specified period. A special field 
experiment using this testing method to measure the cesium release rates from individual fuel assemblies was performed with Materials Test Reactor (MTR) assemblies in Brazil [12]. This experiment involved using fuels with and without through-clad pits, as well as, fuels before and after removal of some of the surface corrosion nodules. A summary of the field examinations is contained in Appendix 2 of this report. Assembly IEA-53, having the greatest extent of pitting corrosion over the fuel meat (see Appendix 2), released 9.24 $\mathrm{nCi} / \mathrm{hr}$ at a constant rate $[5,12]$.

A validation of the release model discussed above is performed by the following calculation using the data from assembly IEA-53. The fuel plates of IEA-53 contained $45 \%$ uranium in aluminum, $20 \%$ enriched in U-235. "The plates had a moderate burn-up of $16.7 \%$ prior to removal from the reactor in 1962. The present Cs-137 activity of the plates is 1.92 $\mathrm{Ci} /$ plate [13]. This corresponds to a fuel core activity of $1.36 \mathrm{Ci} / \mathrm{in}^{3}$. Using an estimate of exposed fuel area of 10 pits of $1 / 4$ inch $(0.635 \mathrm{~cm})$ diameter exposes $0.5 \mathrm{in}^{2}\left(3.2 \mathrm{~cm}^{2}\right)$ of fuel core material and a bounding corrosion rate of 0.2 mils per year, the predicted release rate is $15.5 \mathrm{nCi} / \mathrm{hr}$. This result is in conservative agreement to the measured release rate of $9.24 \mathrm{nCi} / \mathrm{hr}$.

The release of radionuclides is due to aqueous corrosion. Removal of breached Al SNF from water and exposure to air will stop this corrosion, and mitigate the release of radionuclides. Measurements of radioactivity release for fuels heated in air are being performed under a separate Savannah River Technology Center program conducted at Argonne National Laboratory. The results of recent tests to measure the species released from exposed fuel heated at $275^{\circ} \mathrm{C}$ in air have shown no detectable release of any radionuclides from $\mathrm{U}_{2} \mathrm{Si}_{3}-\mathrm{Al}$ fuel in a one-month test [14]. The microstructure of the fuel specimen used in this test is shown in Figure 2.

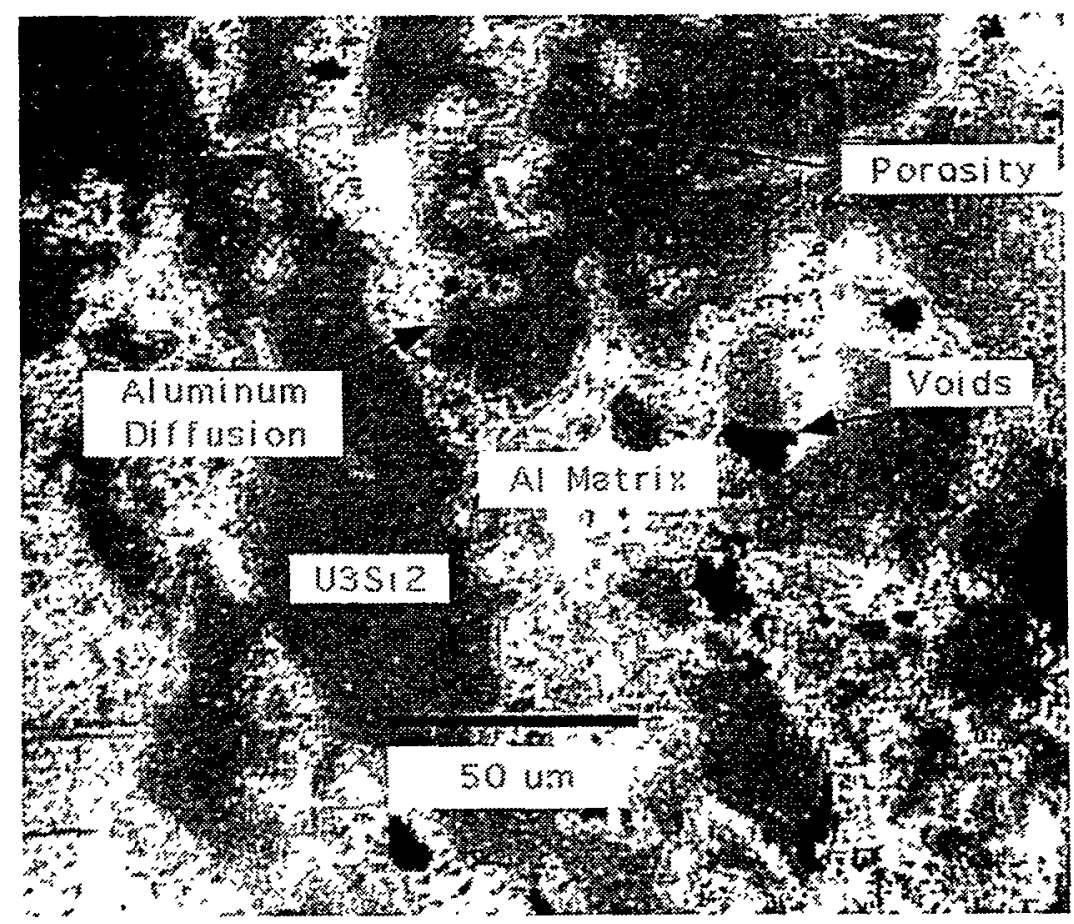

Figure 2- Microstructure of $\mathrm{U}_{2} \mathrm{Si}_{3}-\mathrm{Al}$ Fuel Core following $51.4 \%$ Burn-up (500X) [14]. The black regions are the internal gas pockets 


\section{Impact of Storage of Breached Al SNF on the Authorization Basis for the Operation of the SRS Basins}

\section{Consequences of Release of Activity from the SRS Basins}

The authorization basis for L-Basin and for RBOF are set forth in their respective Basis for Interim Operation $[3,4]$. The safety envelope is established by analyzing the risks associated with various accident scenarios and is based on specific assumptions regarding basin operations, including basin water radionuclide content. The authorization basis for $\mathrm{L}$ Basin [3] limits the basin water cesium concentration to $2000 \mathrm{dpm} / \mathrm{ml}$. Under a worst case accident scenario during which the entire 3.5 million gallons of water at $2000 \mathrm{dpm} / \mathrm{ml}$ is instantaneously evaporated and released to the environment, the consequence to the public is a total dose of $16 \mathrm{mR}$. The on-site worker is exposed to dose rate of $14 \mathrm{mR} / \mathrm{hr}$, within DOE radiological working limits.

The RBOF authorization basis assumes a total basin water activity concentration of $220 ; 000 \mathrm{dpm} / \mathrm{ml}(0.1 \mu \mathrm{Ci})$. The concentration values are higher than the L-Basin values because of the smaller volume of basin water, 500,000 gallons, and past operating history. The maximum activity of the basin water in RBOF has been $220,000 \mathrm{dpm} / \mathrm{ml}$ in one of the isolated basins during fuel handling and cutting operations [4]. A total release of the RBOF water inventory is negligible because it is bounded by an accident analysis of the estimated exposure from a hypothetical tank farm release. The tank farm release assumes a radionuclide inventory release significantly higher than the RBOF water inventory and consequences of worst case scenario for RBOF, similar to L-Basin, is negligible. Therefore, dose estimate impacts to the public and on-site workers from the operation of RBOF were not estimated in its authorization basis. ${ }^{2}$

The basin facilities are managed and operated to much lower limits of radionuclide concentrations through deionization to further improve the safety of facility, maximize ALARA, and minimize waste generation. Although process requirements limit the L Area cesium activity limit to $1000 \mathrm{dpm} / \mathrm{ml}$, the current steady-state cesium activity level is less than $4 \mathrm{dpm} / \mathrm{ml}$ [1]. The current steady-state RBOF activity level is $259 \mathrm{dpm} / \mathrm{ml}$ [2] compared with 15,500 dpm/ml total activity, the Technical Safety Requirement for the facility.

Other radionuclides potentially released from breached fuels include gaseous fission products and noble gases. The risks associated with the release of these radionuclides are bounded by the accident scenario involving an inadvertent criticality in the basins. The postulated criticality releases significantly more gaseous fission products than that released from a breach in the fuel cladding. The doses to the public associated with an inadvertent criticality are insignificant relative to other risks associated with the the L-Basin and relative to other RBOF risks.

The activity release into the basin water is based on the potential releases associated with damaging a reference fuel assembly (RFA) [3]. The release of gaseous fission products and noble gases are not contained in the basin water. In accordance with Safety Guide 1.25 [15], damage of fuel results in the release of $30 \%$ of the $\mathrm{Kr}-85$ and $10 \%$ of other

\footnotetext{
${ }^{2}$ A Safety Analysis Report (WSRC-SA-11) for RBOF is undergoing final approval. The results in this
} present report are consistent with the SAR. 
and noble gases are not contained in the basin water. In accordance with Safety Guide 1.25 [15], damage of fuel results in the release of $30 \%$ of the $\mathrm{Kr}-85$ and $10 \%$ of other noble gases and iodine. A bounding analysis conservatively assumes that 2200 RFA's are damaged concurrently, each containing 1050 curies of $\mathrm{Kr}-85$. No other noble gases are present in the isotopic inventory (see Table 6-1 of reference 3 of this report) as a result of the two year cooling period. A comparison of the total radiological release to the minimum radiological source terms required to meet consequence level thresholds (Tables 6-10 and 6-11 of reference 3 ) results in a determination of low consequences to the facility worker $(<25 \mathrm{rem})$, the onsite worker ( $<500 \mathrm{mrem})$, and the maximum exposed offsite individual (public, $<100$ mrem).

Another important factor in the operations of the basins is the consequence of the cesium loading of the ion exchange resin beds of the deionizer system. The L Area deionizer system design basis was an 8 curie loading of the zeolite beds used for cesium removal. Shielding was designed to maintain the worker dose less than $1 \mathrm{mR} / \mathrm{hr}$. Currently, the zeolite beds only retain 2 curies of cesium before replacement is required because of accumulation of other dissolved solids in the mixed beds. The postulated addition of 1500 breached clad assemblies would increase the zeolite loading from 2 curies to slightly less than 8 curies, before change out, still within the design basis of the system, safety authorization, and with no increase in waste volume. Similarly, the RBOF resin beds are regenerated twice per year, and no change to the schedule or additional waste volume would result due to the storage of 1500 BRFAs. Only the curie loading would increase. Shielded cells and remote resin handling equipment preclude additional worker dose.

\section{Impact of Postulated Release Rates on Water Activity Relative to the Authorization Basis}

As stated, the Basis for Interim Operation of the SRS basins assumes a limit of 2000 $\mathrm{dpm} / \mathrm{ml}$ for Cs-137 for L-Basin and $220,000 \mathrm{dpm} / \mathrm{ml}$ total activity for RBOF $[3,4]$. The steady-state activity level during basin operation is dependent on the deionization capacity and the releases into the basin from sludge, basin walls, contamination on spent fuel, and exposed fuel material. With the new deionization system in L-Basin, the current water activity level is less than $4 \mathrm{dpm} / \mathrm{ml}$ [1]. The current water activity level in RBOF is 259 $\mathrm{dpm} / \mathrm{ml}[2]$.

A calculation is performed for the postulated storage scenario of $1500 \mathrm{Al} \mathrm{SNF}$ assemblies with breached fuel cladding to evaluate the increase in activity level of the water. A breached reference fuel assembly (BRFA) is developed from the Reference Fuel Assembly (RFA) used in the safety basis for the SRS basins [3] and which bounds the worst case breach observed in the field inspections performed through the Foreign Research Reactor Fuel receipts. The Cs-137 loading of the RFA is $9280 \mathrm{Ci}$ [3]. The RFA is actually for a storage location rather than an individual assembly and six assemblies are typically stored per location. The research reactor fuels are primarily the Materials Test Reactor design. These fuels have 18 fuel plates each with a nominal fuel core volume of $23.5^{\prime \prime} \times 2.5^{\prime \prime} \mathrm{x}$ 0.02 ". The volumeric Cs-137 loading of the BRFA is simply calculated to be $9280 \mathrm{Ci}$ per storage location/(6 assemblies per storage location $\mathrm{x} 18$ fuel plates per MTR assembly $\mathrm{x}$ $23.5^{\prime \prime} \times 2.5^{\prime \prime} \times 0.02$ " per plate) or $73.1 \mathrm{Ci} / \mathrm{in}^{3}$.

A value of $0.5 \mathrm{in}^{2}$ of exposed fuel core is equivalent to ten $1 / 4$ " diameter through-clad pits, equivalent to the worst pitted assembly observed during the field inspections to date. Using 1500 BRFAs with 0.5 in $^{2}$ of exposed fuel is bounding and takes into account the 
possibility that some fuels could have more or less exposed core material. Thus, the BRFA is defined as a reference fuel assembly with a:

- Cs-137 loading of $73.1 \mathrm{Ci} / \mathrm{in}^{3}$ of fuel material; and an

- Exposed fuel core region of $0.5 \mathrm{in}^{2}$.

Using the release rate model described above, the release rate from the RBFA in basin water is $0.00731 \mathrm{Ci} /$ year, or $0.835 \mu \mathrm{Ci} / \mathrm{hr}$.

Under steady-state conditions, the deionizer system will remove soluble radioactivity (e.g. Cs-137) and suspended insoluble radioactive particles at a rate equal to the total release rate into the basin. The removal rate is a function of the system flow rate and the radioactivity concentration of the water. This steady state condition is expressed as follows:

$$
\mathrm{Q} \cdot \mathrm{C}=\mathrm{A} \cdot \mathrm{V}
$$

where: $Q=$ flow rate through the system (gal/day)

$$
\begin{aligned}
& \mathrm{C}=\text { steady-state activity of the water }(\mathrm{dpm} / \mathrm{ml}) \\
& \mathrm{A}=\text { activity release rate to the water }(\mathrm{dpm} / \mathrm{ml} / \text { day) } \\
& \mathrm{V}=\text { basin volume (gal) }
\end{aligned}
$$

The deionizer systems at SRS are designed for continuous operation. The average flow rate, Q, for the L-Basin deionizer is assumed to be $200 \mathrm{gpm}$. The volume of L-Basin is $3,375,000$ gallons. For a postulated scenario of $1500 \mathrm{BRFAs}$, each releasing Cs-137 at $0.835 \mu \mathrm{Ci} / \mathrm{hr}$ into the basin, $A$ is calculated to be $5.22 \mathrm{dpm} / \mathrm{ml} /$ day. The steady-state concentration $C$ is calculated to be $61.1 \mathrm{dpm} / \mathrm{ml}$. This is the estimated increase to the present steady-state concentration of approximately $4 \mathrm{dpm} / \mathrm{ml}$. Recent trending data collected with the L-Basin deionizer system inactive shows the activity increase rate to be approximately $0.31 \mathrm{dpm} / \mathrm{ml} /$ day [1] resulting from the inventory of "at-risk" Mk-16 fuel, basin sludge, and basin wall contamination. The graph in figure 3 shows that the L-basin deionizer system could be inactive for 350 days before the authorized limit would be exceeded. In comparison, the same calculation performed for 1500 assemblies releasing Cs-137 at $9.24 \mathrm{nCi} / \mathrm{hr}$, the release rate measured for assembly IEA-53, results in a release rate of $0.0578 \mathrm{dpm} / \mathrm{ml} /$ day and a steady-state concentration, $C$, of $0.475 \mathrm{dpm} / \mathrm{ml}$; the deionizer system could be inactive for 14.9 years before the authorized limit would be exceeded.

For $\mathrm{RBOF}$, the flow rate through the deionizer, $\mathrm{Q}$, is approximately $100 \mathrm{gpm}$ and the basin volume is 500,000 gallons. For the same postulated scenario of $1500 \mathrm{BRFAs}$ each releasing Cs-137 at $0.835 \mu \mathrm{Ci} / \mathrm{hr}$ into the basin, $\mathrm{A}$ is calculated to be $35.2 \mathrm{dpm} / \mathrm{ml} / \mathrm{day}$. The steady-state concentration $C$ is calculated to be $123 \mathrm{dpm} / \mathrm{ml}$; this is the estimated increase to the present steady-state concentration of $259 \mathrm{dpm} / \mathrm{ml}$ [2]. Recent trending data collected with the RBOF deionizer system inactive shows the activity increase rate to be approximately $36 \mathrm{dpm} / \mathrm{ml} /$ day [2]. The graph in figure 4 shows that the RBOF system could be inactive for 8.5 years before the authorized limit would be exceeded. This provides sufficient time to implement portable deionizer systems, if necessary. 


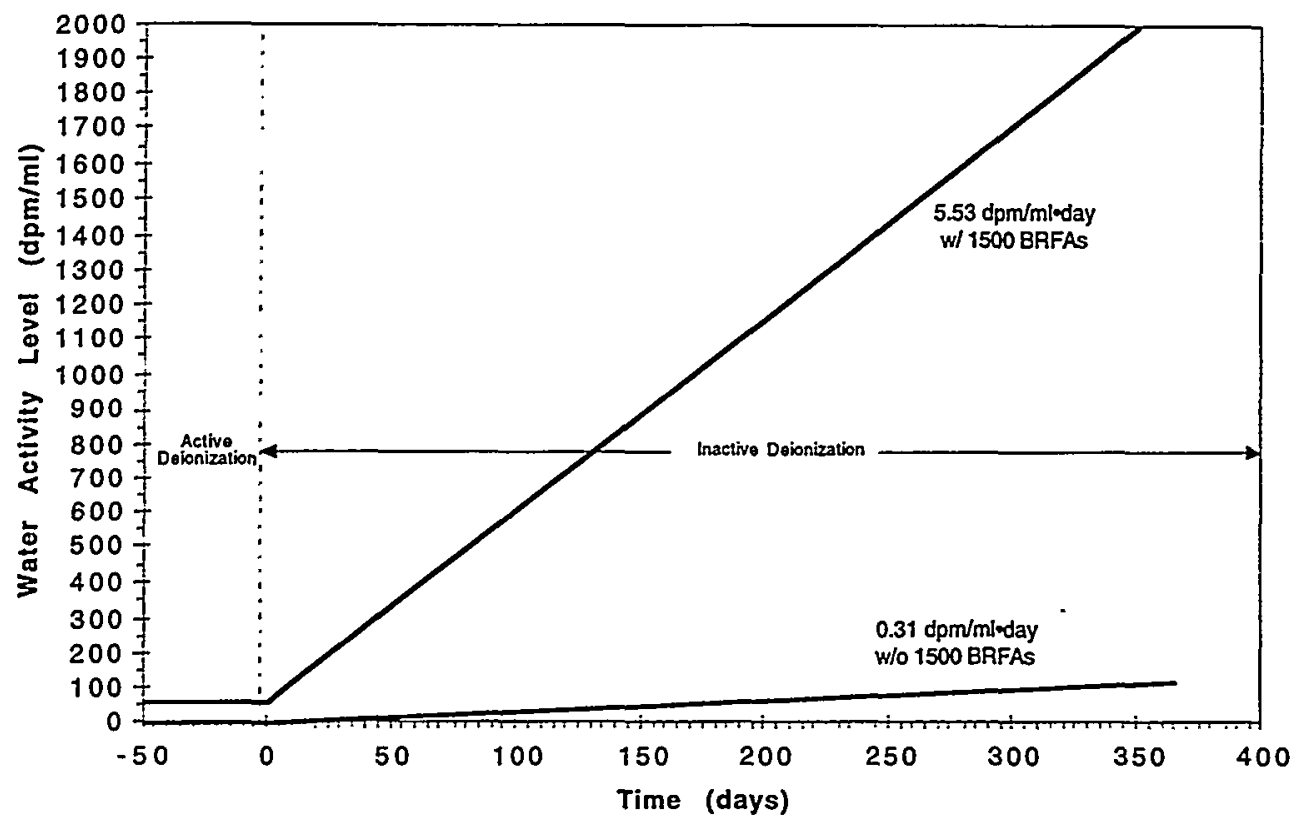

Figure 3- Water Activity Level for L-Basin With and Without Storage of 1500 MTR Assemblies Each Releasing Cs-137 at $0.835 \mu \mathrm{Ci} / \mathrm{hr}$

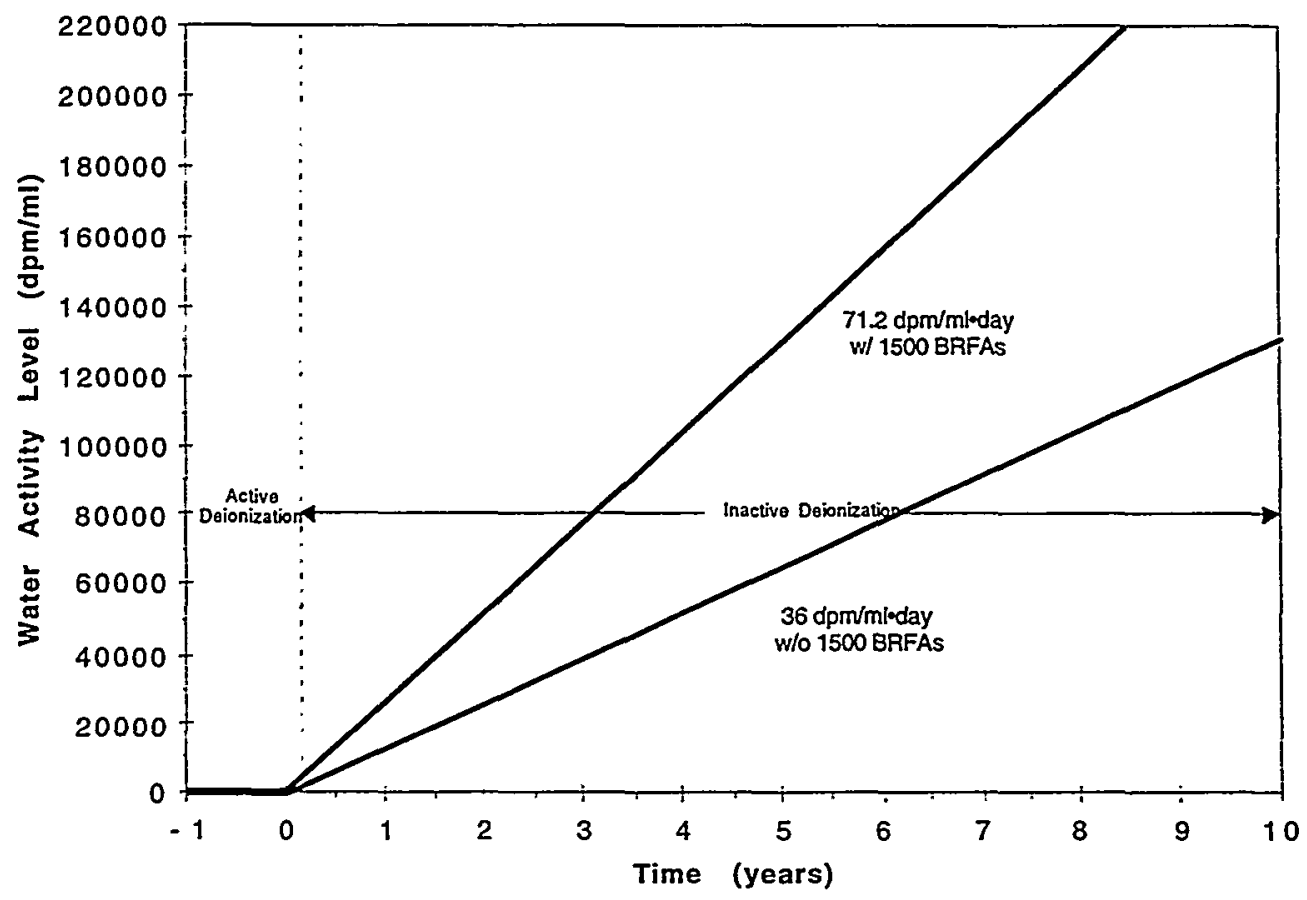

Figure 4- Water Activity Level for RBOF With and Without Storage of 1500 MTR Assemblies Each Releasing Cs-137 at $0.835 \mu \mathrm{Ci} / \mathrm{hr}$ 


\section{CONCLUSIONS}

A release rate model was developed for aluminum-based spent nuclear fuel (Al SNF) with breached cladding. The measured release rates from fuels in basin storage are consistent with the model. The anticipated release for a conservative bounding scenario of 1500 breached reference fuel assemblies (BRFAs) stored in SRS basins was determined. The application of the model showed that the storage of each BRFA will result in a release rate of $0.835 \mu \mathrm{Ci} / \mathrm{hr}$ of $\mathrm{Cs}-137$. With active deionization, the basin water activity levels are estimated to be $65.1 \mathrm{dpm} / \mathrm{ml}$ and $382 \mathrm{dpm} / \mathrm{ml}$, well below the authorization basis limits of $2000 \mathrm{dpm} / \mathrm{ml}$ and $220,000 \mathrm{dpm} / \mathrm{ml}$ for L-Basin and RBOF, respectively. In the event the deionization systems are inactive, the authorized limits would not be exceeded for 350 days and 8.5 years for $L$ Basin and RBOF, respectively. Fully demonstrated portable deionizers could be brought online within these time periods, if necessary. Although storage of the breached fuels would cause an increase in the curie loading of the waste streams, there would be no increase in the volume of waste generated. The increased curie loading is within the design bases of the facilities and allowed under the authorization bases.

\section{REFERENCES}

1. Trending data of L-Basin water activity, R. W. Deible to R. L. Sindelar, May 1997.

2. Trending data of RBOF water activity, R. M. Benson to R. L. Sindelar, May 1997.

3. WSRC-TR-95-0054, Rev. 0, "Basis for Interim Operation (BIO) for the LReactor Facility (U)," Westinghouse Savannah River Co. report, July 1996.

4. WSRC-TR-94-0287, Rev. 1, "Basis for Interim Operation (BIO) for the Receiving Basin for Offsite Fuels (RBOF) and the Resin Regeneration Facility (RRF) (U)," Westinghouse Savannah River Co. report, March 1995.

5. WSRC-TR-96-0401, "Criteria for Acceptance of Off-Site Spent Nuclear Fuel at SRS (U)," R. L. Sindelar and J. P. Howell, Westinghouse Savannah River Co., December 1996.

6. DOE (U.S. Department of Energy) 1996, Final Environmental Impact Statement, Proposed Nuclear Weapons Non-Proliferation Policy Concerning Foreign Research Reactor Spent Nuclear Fuel, DOE/EIS-0218, Assistant Secretary for Environmental Management, Washington, D.C.

7. ANL/NPR-90/008, "Evaluation of Existing Technology Base for Candidate Fuels and Target Materials for the HWR-NPR," by J. L. Snelgrove, G. L. Hofman, R. L. Frontroth, W. R. McDonell, H. B. Peacock, R. F. Whitacre, and G. L. Copeland, Argonne National Laboratory Report, March 1990.

8. WSRC-TR-95-343, "Corrosion of Aluminum Alloys in Wet Spent Fuel Storage (U)," J. P. Howell, Westinghouse Savannah River Co., September 1995.

9. "Corrosion of Aluminum Clad Fuel and Target Elements: The Importance of Oxide Films and Irradiation History," M. R. Louthan, Jr., R. L. Sindelar, N. C. Iyer, and H. B. Peacock, Jr., American Nuclear Society, Proceedings of the Embedded Topical Meeting on DOE Spent Nuclear Fuel and Fissile Material Management, Reno, Nevada, June 16-20, 1996, pp. 57-61. 
10. "Evaluation of Water Chemistry on the Pitting Susceptibility of Aluminum, G. T. Chandler, R. L. Sindelar, and P. S. Lam, National Association of Corrosion

Engineers International, Houston, TX, Paper No. 104 at CORROSION/97, March 1997.

11. "An Evaluation of the Thickness and Emittance of Aluminum Oxide Films Formed in LowTemperature Water," J. K. Thomas and R. S. Ondrejcin, Journal of Nuclear Materials, 199 (1993) pp. 192-213.

12. SRT-MTS-962041, "TRIP REPORT: Characterization of IEA-R1 Spent Nuclear Fuels at the IPEN, Sao Paulo, Brazil, July 22 - July 31, 1996 (U)," R. L Sindelar, H. B. Peacock, Jr., J. P. Howell, S. D. Burke, and A. S. Busby, September 4, 1996.

13. Calculations performed at the IPEN using ORIGEN2, communication J. A. Perrota to R. L. Sindelar, July 30, 1996.

14. "SRTC Fission-Product Collection Test 96-1," December 4, 1996, A. B. Cohen, Argonne National Laboratory, transmitted A. B. Cohen to N. C. Iyer, April 3, 1997.

15. "Assumptions Used for Evaluating the Potential Radiological Consequences of a Fuel Handling \& Storage Facility for Boiling \& Pressurized Water Reactor," Safety Guide 1.25 , U. S. Nuclear Regulatory Commission, Washington, D. C., $4 / 23 / 72$. 


\section{APPENDIX 1- Corrosion of Aluminum-Clad SNF in Wet Basin Storage}

Corrosion of aluminum alloys and production fuels at SRS and other water storage facilities has been documented [1-3]. Corrosion of the aluminum-clad and the uraniumaluminum alloy fuel core in water storage basins can be attributed to poor quality water at some point in the fuel storage lifetime. Corrosion surveillance tests at SRS have shown that storage in poor quality water can result in pitting corrosion of aluminum alloys. Pit depths of 30 mils, equivalent to the cladding thickness of SRS fuel, were measured on coupons exposed to aggressive basin conditions for 2 months in water with a conductivity of approximately $200 \mu \mathrm{S} / \mathrm{cm}$. Under aggressive water condition, the corrosion product on the aluminum cladding is characterized, generally, by crusted nodules of aluminum oxide located primarily in scratches in the protective oxide coating formed during fuel irradiation [4]. These thinned areas make it easier for aggressive ions like chlorides to attack the aluminum. As aluminum oxide is formed, an occluded cell with an aggressive, acidic environment can develop beneath the nodule. This can result in a rapid pit formation in the alloy, penetrating the cladding thickness in short time periods. Visible signs of crusted oxide nodules on aluminum indicate that pitting corrosion has taken place and there is attack beneath these nodules and a high probability of penetration of the cladding.

Pitting corrosion is difficult to predict from water composition alone because of the synergistic nature of the aggressive impurities and the variables involved [1-3]; however, recent laboratory data have shown that water solutions with conductivities less than $50 \mu \mathrm{S} / \mathrm{cm}$ are non-aggressive to cause pitting corrosion and that the chloride ion may be the controlling factor for pit initiation under basin conditions [5]. The major environmental factors believed to influence the pitting of aluminum alloys are [1-3]: conductivity, $\mathrm{pH}$, bicarbonate, chloride, sulfate, and oxygen content of the water. In addition, the corrosion process is enhanced by the aluminum/steel dissimilar metal couples which exist throughout most basins. Heavy metals like copper and mercury and noble metals like silver can plate out on the aluminum forming strong localized anodic/cathodic sites which promote aggressive pitting of the aluminum.

In contrast, pitting corrosion has not been seen on aluminum cladding and corrosion surveillance coupons stored in high quality water. The water in RBOF has been maintained with a conductivity in the $1-3 \mu \mathrm{S} / \mathrm{cm}$ range and aggressive impurity concentrations in the parts-per-billion range. After an extensive campaign over the last several years to cleanup the reactor basins which has included sludge removal, new continuous deionization equipment installation, and new aluminum storage racks, all basins at SRS are being maintained below $4 \mu \mathrm{S} / \mathrm{cm}$. No new pitting corrosion has been seen in the reactor basins since 1993.

Field tests have shown that pitting corrosion is mitigated when the pitted materials are exposed to high quality water. Fuels that contained through-clad pits with surface corrosion nodules were measured to determine radionuclide release before and after removal of the nodules using a sip test with high purity, low conductivity water [6]. The release rates of Cs-137 from the pitted fuel before and after the removal of the nodules were identical which indicates that an aggressive water chemistry does not exist under the nodules when placed in high quality basin water.

\section{References}

1. D. Z. Nelson and J. P. Howell, "Metallography of Pitted Aluminum-Clad Depleted Uranium Fuel," National Association of Corrosion Engineers International, Houston, TX, NACE'95, Paper 430, March 1995. 
2. J. P. Howell, "Durability of Aluminum-Clad Spent Fuels in Wet Basin Storage" National Association of Corrosion Engineers International, Houston, TX, NACE'96, Paper 128, March 1996.

3. J. P. Howell, "Corrosion Surveillance in Spent Fuel Storage Pools," National Association of Corrosion Engineers International, Houston, TX, NACE'97, Paper 107, March 1997.

4. M. R. Louthan, Jr., R. L. Sindelar, N. C. Iyer, and H. B. Peacock, Jr., "Corrosion of Aluminum Clad Fuel and Target Elements: The Importance of Oxide Films and Irradiation History,". American Nuclear Society, Proceedings of the Embedded Topical Meeting on DOE Spent Nuclear Fuel and Fissile Material Management, Reno, Nevada, June 16-20, 1996, pp. 57-61.

5. G. T. Chandler, R. L. Sindelar, and P. S. Lam, "Evaluation of Water Chemistry on the Pitting Susceptibility of Aluminum," National Association of Corrosion Engineers International, Houston, TX, NACE'97, Paper 104, March 1997.

6. SRT-MTS-962041, "TRIP REPORT: Characterization of IEA-R1 Spent Nuclear Fuels at the IPEN, Sao Paulo, Brazil, July 22 - July 31, 1996 (U)," R. L Sindelar, H. B. Peacock, Jr., J. P. Howell, S. D. Burke, and A. S. Busby, September 4, 1996. 


\section{APPENDIX 2- Examination of Brazilian Research Reactor MTR Fuel}

A team of scientist and engineers from SRS visited the Institute for Nuclear Energy Research of the Nuclear Energy Commission at Sao Paulo (IPEN/CNEN-SP), Brazil July $22-31,1996$ [1] to characterize the extent of corrosion and the effect of this corrosion on the release of radionuclides from this fuel to the research reactor basin water.

Using an underwater video camera system, along with an $8 \mathrm{~mm}$ video camcorder above the surface of the basin, detailed inspections were made on 66 SNF assemblies which had been stored in the basin water environment for 25-35 years. Nodules of white corrosion products on the outside fuel plates of 41 assemblies were visible to the eye from above the water surface. Hard crusted mounds of aluminum oxide ranged in sizes from about 1/32 inch to $1 / 4-1 / 2$ inch in diameter as estimated by comparison with drilled holes in the edges of the side plates known to be 0.096 inches in diameter. These oxide nodules are shown on an external fuel plate from IPEN fuel assembly No. 53 below in Figure 1.

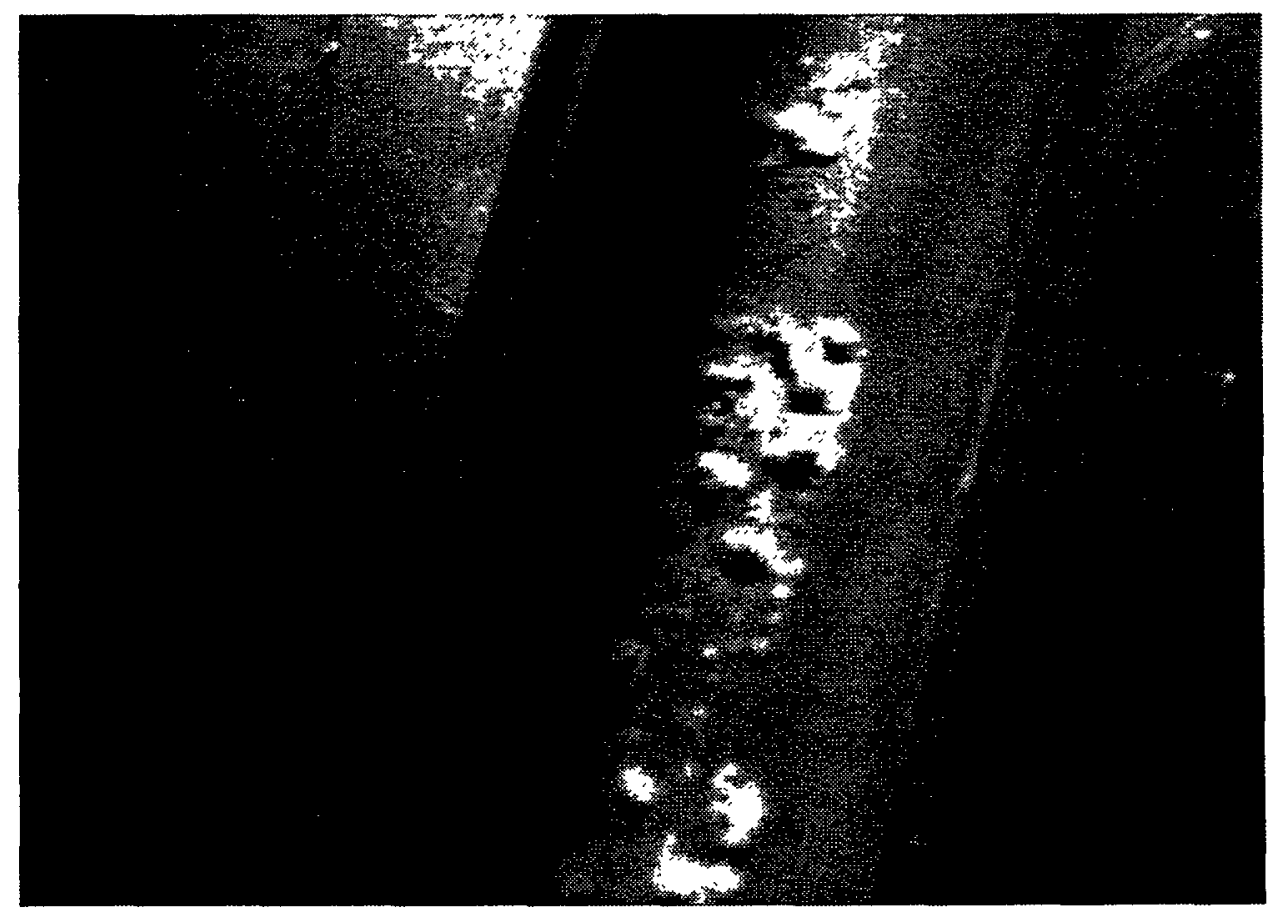

Figure 1- Assembly IEA-53 Before Removal of Nodules

This assembly was selected for an in-depth examination because it showed among the highest leach rates of Cs-137 as determined by a sip test. In addition, this assembly had the largest deposits of visible corrosion product over the fuel plates. This corrosion was typical of the corrosion seen on most of the 41 assemblies. Without exception, every large nodule of oxide of was associated with a thru-clad pit in the aluminum cladding beneath the corrosion product. This was determined by brushing or scraping the oxide nodule to remove from the fuel plate to reveal the pit below. Figure 2 shows typical through-clad pits after oxide removal from some of the nodules on the fuel plate of assembly IEA-53. The pits were judged to be through the 0.015 mil cladding by comparison with the known 0.096 mil diameter holes drilled in the side plates. Analysis of the nodular corrosion product using gamma ray spectroscopy showed uranium-235, europium-154, and cesium137 , confirming that the pit associated with the nodule had breached the cladding into the fuel core. 


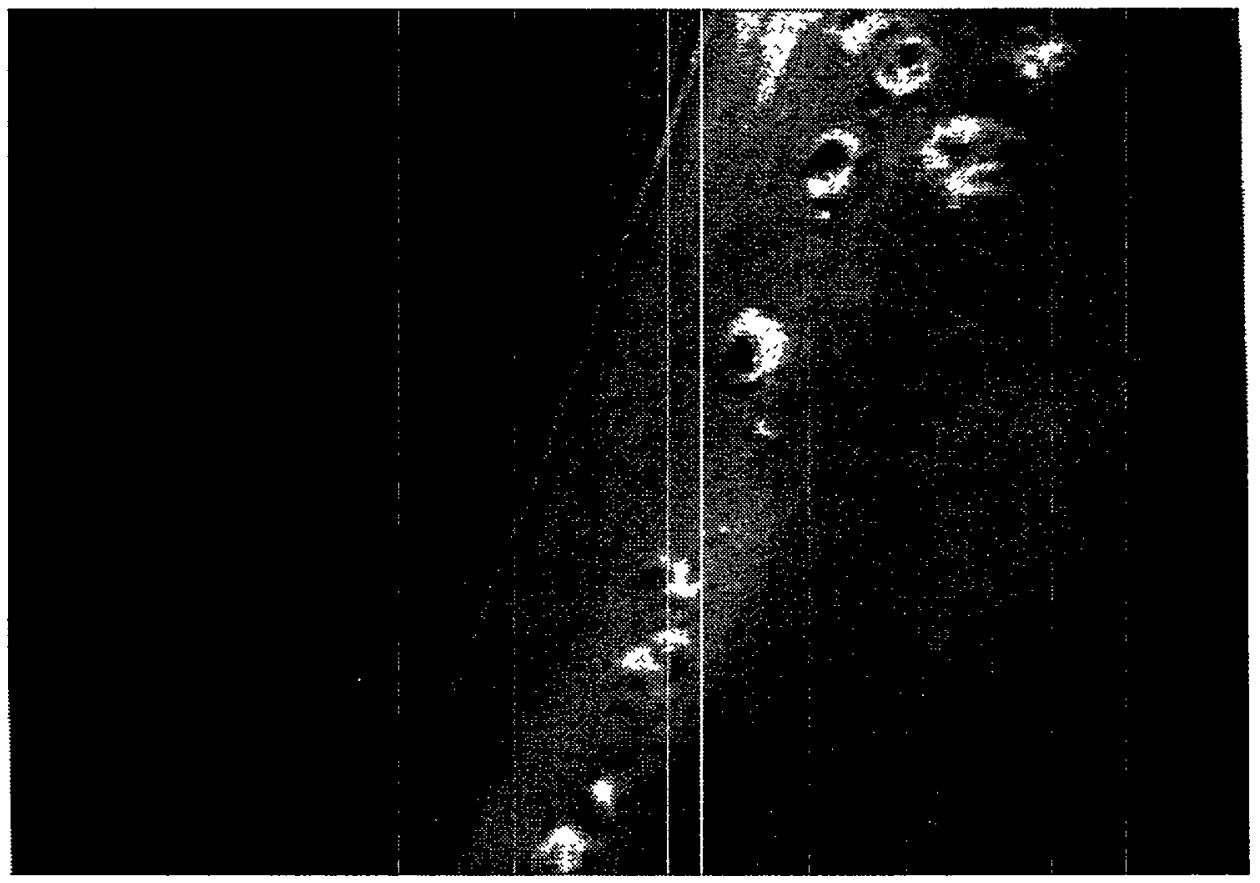

Figure 2- Assembly IEA-53 After Removal of Nodules

At the time of this underwater fuel inspection, this visual examination was the most extensive examination of Al SNF in water storage basin in the world. It showed that based on the size of the visible corrosion nodule as compared to known reference dimensions on the fuel, a judgment can be made on the size of the pit beneath this product. As the cladding thickness on the research reactor fuel is relatively thin compared to the diameter of the oxide nodules, the pits generated in the surface of the fuel plates have a high probability of penetrating the clad into the U-Al core.

The details of the sip tests of the Brazil fuels are contained in reference 1.

\section{References}

1. SRT-MTS-962041, "TRIP REPORT: Characterization of IEA-R1 Spent Nuclear Fuels at the IPEN, Sao Paulo, Brazil, July 22 - July 31, 1996 (U)," R. L Sindelar, H. B. Peacock, Jr., J. P. Howell, S. D. Burke, and A. S. Busby, September 4, 1996. 
WESTINGHOUSE SAVANNAH RIVER CO. Report WSRC-TR-97-0153

DISTRIBUTION

\section{SAVANNAH RIVER SITE}

I. B. New, 704-C

G. H. Clare, 704-C

B. K. Chambers, DOE-SR, 704-K

S. Wood, 773-A

G. T. Wright, 773-A

C. R. Wolfe, 773-A

T. L. Capeletti, 773-41A

R. J. Skwarek, 704-C

D. C. Wood, 704-C

S. D. Burke, 707-C

S. R. Smith, 707-C

B. D. Clark, 707-C

E. R. Conatser, 704-C

S. W. O'Rear, 707-C

M. E. Dupont, 707-C

J. R. McEntire, Jr., 707-C

M. W. Barlow, 704-C

J. R. Murphy 707-C

H.M. Brooks, 707-C

K. J. Durrwachter, 707-C

J. C. Guy, 707-C

R. W. Deible, 707-C

R. M. Benson, 707-C

J. F. Zino, 730-B

N. C. Iyer, 773-A

M. R. Louthan, Jr., 773-A

J. P. Howell, 773-41A

W. F Ayres, 773-41A

R. L. Sindelar, 773-41A 